TEME, г. XLIII, бр. 4, октобар - децембар 2019, стр. 1187-1199

Прегледни рад

Примљено: 1. 11. 2019.

https://doi.org/10.22190/TEME191101071D

Ревидирана верзија: 3. 11. 2019.

Одобрено за штампу: 1. 12. 2019.

\title{
RESPONSIBILITY OF CONVICTED AND MAINTENANCE OF ORDER AND SECURITY IN PENITENTIARY INSTITUTIONS $^{a}$
}

\author{
Darko Dimovski ${ }^{*}$, Ivan Milić ${ }^{2}$ \\ ${ }^{1}$ University in Niš, Faculty of Law, Niš, Serbia \\ ${ }^{2}$ University of Novi Sad, Faculty of Law, Novi Sad, Serbia \\ *darko@prafak.ni.ac.rs
}

\begin{abstract}
In the Republic of Serbia, there are more than thirty penitentiary institutions in which convicted offenders serve their prison sentences. These are prisons of different types: closed, semi-closed and open prisons. At the same time, convicts are not the only ones placed in prisons, but also other persons deprived of their liberty by law. Apart from offenders convicted for the commission of criminal offences, these penitentiary institutions also house other persons who are lawfully deprived of liberty under the law for the commission of a misdemeanour or for the failure to pay a fine or do community service. A common feature shared by all these categories of people is the liability for the committed offence but, depending on the specific type of liability, they are subject to different treatment in penal institutions. In such circumstances, penal institutions have to take relevant measures to maintain order and security in prisons.

The paper explores a number of issues related to convicts and other inmates in prisons. The authors first focus on three different types of liability: criminal liability, disciplinary liability, and material liability, which clearly imply different treatments of convicts and inmates in the course of serving their term of imprisonment. Then, the authors address the problems of maintaining order and security in prisons. Generally speaking, the law that applies to persons serving their sentences in a penal institution is the Act on the Execution of Criminal Sanctions but, depending on the committed crime, they may also be subject to the Act on the Execution of Imprisonment for Organized Crime. Thus, the authors discuss the legal solutions pertaining to this subject matter as contained in both legislative acts.
\end{abstract}

Key words: convicts, responsibility, order maintenance, security.

\footnotetext{
${ }^{a}$ The work was realized within the project "Protection of human and minority rights in the European legal area" no. 179046 of the Ministry of Education, Science and Technological Development of the Republic of Serbia.
} 


\title{
ОДГОВОРНОСТ ОСУЂЕНИКА И ОДРЖАВАЫЕ РЕДА И БЕЗБЕДНОСТИ У КАЗНЕНИМ ЗАВОДИМА
}

\begin{abstract}
Апстракт
У Републици Србији постоји више од тридесет затворских установа у којима осуђени преступници издржавају затворске казне. То су затвори различитог типа: затворени, полузатворени и отворени затвори. У исто време, осуђени нису само они који су смештени у затворе, већ су то и друга лица која су законом лишена слободе. Осим осуђених за извршење кривичних дела, у ове казнено-поправне установе смештају се и друга лица која су лишена слободе по закону због извршења прекршаја или због неплаћања новчане казне или обављања казне рада у јавном интересу. Заједничка карактеристика коју деле све ове категорије људи је одговорност за почињено кривично дело, али зависно од посебне врсте одговорности, они су изложени различитом поступању у казненим установама. У таквим околностима, казнене установе морају предузети одговарајуће мере за одржавање реда и сигурности у затворима. У средишту пажње аутора је неколико питања која се тичу осуђеника у казненим заводима. Аутори указују на видове одговорности осуђеника за време издржавања казне затвора, и то кривичну, дисциплинску и материјалну одговорност. Аутори су пажњу посветили и проблемима одржавања реда и безбедности у казненим заводима. Имајући у виду чињеницу да се према лицу које издржава казну у казненом заводу примењује Закон о извршењу кривичних санкција, али да може да се примењује и Закон о извршењу казне затвора за кривична дела организованог криминала, аутори указују на решења оба закона која се односе на предметну материју.
\end{abstract}

Кључне речи: осуђеници, одговорност, одржавање реда, безбедност.

\section{INTRODUCTION}

From the day the convict enters a penal institution where they are to serve the awarded prison sentence, they are subject to special rules of conduct - prison rules. These rules are valid from the moment when the convicted person enters the institution until the moment when they have served their sentence in the penitentiary. The rules of conduct in prisons are regulated by the law (legislative acts), as well as by by-laws (administrative acts). The prisons themselves are also entitled to pass certain regulatory acts that regulate the rules of conduct of convicts and inmates. Obviously, the convicted persons must behave in accordance with all the rules that are enforced at the penitentiary; otherwise, they bear some responsibility - may bear the consequences of failing to abide by the rules, and they may be held accountable for the violation of prison rules. The rules of conduct are strict. In addition to these strict prison rules, which are embodied in normative acts, the convicts' conduct is most likely to be influenced by a set of informal norms of behavior. These norms, which are usually short and straightforward, determine the behavior of convicts not only towards the formal penal system, but also towards other members of the informal system (Dimovski, Kostic, 2018, p. 1054).

If a convicted person does not comply with the regulations and lawful orders of the authorized persons, they commit a disciplinary offense. 
Such a convict is subject to disciplinary proceedings, and disciplinary measures are imposed if the existence of the offense and their responsibility are established. The violation of prison discipline is prescribed as a disciplinary offense.

Convicted persons may commit a criminal offense while serving their imprisonment sentences, in which case they are held liable under the same conditions as persons who are not serving the sentence in a penal institution. There is one exception to this rule. Namely, the convicted person can cause damage to the penal institution in which they are serving their sentence. In this case, the convict bears material responsibility; one specificity in such a case is who decides on the compensation for damage.

While serving prison sentences, some convicts may need to be subjected to certain preventive measures which are taken because there is a danger that they may impair their health or endanger the order and security at the penitentiary.

All cases of convicts' disorderly conduct are recorded and kept as penitentiary records, and such conduct may necessarily affect the scope of convicts' rights and benefits while serving their sentence, which may be reflected in the individual treatment in the course of the execution of the prison sentence.

\section{WHO IS PLACED IN PENITENTIARIES IN THE REPUBLIC OF SERBIA?}

The prison population is comprised not only of convicted offenders committed to serve their prison sentences there, but also of persons deprived of their liberty for various legal reasons. Certainly, individuals convicted in criminal proceedings and sentenced to imprisonment make the highest percentage of prison population. Yet, it also includes individuals whose imprisonment is due to misdemeanor offenses, as well as a certain number of persons who have been fined, or sentenced to community service in criminal proceedings - sentences substituted for imprisonment due to non-payment of the imposed fine or due to failure to perform community sentence. The same goes for persons who have committed a misdemeanor. A person who is found liable for the commission of an economic offense may also be placed in the penitentiary; if they fail to pay the imposed fine, it is substituted by a term of imprisonment. Therefore, persons deprived of liberty are placed in prisons on different legal grounds and, thus, they have different treatment during their imprisonment. A common feature for all of them is that they cannot leave the penitentiary, except when permitted by law. Also, during the execution of the prison sentence, they are obliged to act in accordance with the law and regulations issued on the basis of the law, and abide by the orders of prison officials unless the execution of the order is unlawful. 


\section{RESPONSIBILITY OF CONVICTS IN PRISON}

While serving a sentence of imprisonment in the penitentiary, convicted persons can commit a prohibited act, which may be regarded either as a criminal offense or a disciplinary offense. If a convicted person commits a criminal offense or a disciplinary offense, they will be held liable. In addition to criminal and disciplinary liability, there is also material liability which exists if the convicted person causes damage to the penitentiary.

\section{Criminal Liability of Convicts while Serving a Prison Sentence}

The commission of a crime while serving a prison sentence is not common. We may certainly pose the question of how many of these offences go undetected. It is logical that a convicted person in a penitentiary cannot commit a criminal offense that they could commit at large. Convicts in prisons usually commit crimes against life and limb. The passive subject (the victim) is usually another convict. If a convicted person commits a criminal offense in a penal institution, his liability is the same (established on the same grounds) as if they committed the criminal offense at large. Criminological studies have shown that persons most prone to violence, both in and out of prison, are between the age of 16 and 24. The average age of persons admitted to penitentiary institutions is 27 years. It is also shown that young people are more likely to be victimized by various forms of violence than adults (Clear, Cole, \& Reisig, 2009, p. 278). However, there are no detailed studies in the Republic of Serbia on the extent of prison violence committed by members of different collectives. Although records are kept of the extent of violence in Serbian prisons, it is not possible to find in any statistical record whether a particular violent event occurred as a result of the disruption of relations within the collective or conflict between the inmates. Specifically, conflicts between prisoners can occur as a result of a criminal event involving several persons currently serving a prison sentence. Therefore, the reasons for verbal and physical conflicts should not only be sought in relationships between collectives and their members, but also in prisoners' relationships before their conviction (Dimovski, Kostic, 2018, p. 1052).

Regarding the criminal responsibility of a convicted person while serving a prison sentence, there is an exception prescribed by the Serbian Criminal Code. A convicted person who commits a criminal offense for which the law prescribes a fine or imprisonment of up to one year, while serving a sentence of imprisonment or while in juvenile prison, is punishable by disciplinary action (Article $62 \mathrm{CC}$ ). ${ }^{1}$ In this case, prison authorities do not

\footnotetext{
${ }^{1}$ Art. 62 of the Criminal Code, "Official Gazette RS ", no. 85/2005, 88/2005,
} 107/2005, 72/2009, 111/2009, 121/2012, 104/2013, 108/2014, 94/2016, 35/2019 
raise criminal charges against the convicted person; instead, they initiate a disciplinary proceeding against the inmate. Although it is not explicitly prescribed, the convicted person should be held liable as if he or she committed a serious disciplinary offense. In this case, disciplinary proceedings are conducted by a disciplinary commission, which may impose disciplinary measures on the convicted person.

\section{Disciplinary Responsibility of Convicted Persons}

Life in penal institutions is governed by strict rules, prescribed both by the law and by-laws, as well as by the regulations adopted by prisons themselves. In addition, officials have the authority to issue orders to convicted persons. Strict rules must be observed in these institutions because it is the only way to maintain order and discipline in penitentiaries (Milić, Dimovski, 2016, pp. 219-231). If convicted persons violate the rules of conduct, such an act constitutes a disciplinary offense. Disciplinary offenses are prescribed by the Act the Execution of Criminal Sanctions (hereinafter: ECS Act) and they are divided into more major and minor disciplinary offences. If it is established in a disciplinary proceeding that the convicted person has committed a disciplinary offense and that they are liable, they will be imposed the appropriate disciplinary measure. Disciplinary measures may be said to be repressive measures because they are imposed only after the existence of the disciplinary offense, and the defendant's responsibility has been established in the disciplinary proceedings (Drakić, Milić, 2016, pp.475-491).

\section{Material Liability of Convicted Persons}

In addition to committing a disciplinary offense while serving their sentence, a convicted person may cause damage to the penal institution. In such a case, the convicted person is obliged, under certain conditions, to compensate the damage. A convicted person may cause damage to the institution by the very act for which they committed a disciplinary offense, but it may also cause damage regardless of disciplinary responsibility. The first instance disciplinary authority decides on compensation amounting to $15,000 \mathrm{RSD}$, whereas the compensation for damage exceeding 15,000 RSD is carried out in civil proceedings. ${ }^{2}$

It is interesting that the legislature has stipulated that the first instance disciplinary authority may decide on compensation for damage. A convicted person may cause damage to a penal institution when committing a disciplinary offense, or without committing a disciplinary offense. In that respect, there are two distinctive situations.

${ }^{2}$ Art. 177 of the Act on Execution of Criminal Sanctions, "Official Gazette RS ", no. 55/2014, 35/2019. 
In the first case, the applicant seeking the initiation of disciplinary proceedings will also file a compensation claim. ${ }^{3}$ Such a decision is probably prescribed on the basis of criminal proceedings, in which the court can decide on a compensation claim. Although in principle there is justification for such a prescription, as well as justification for the criminal court to decide on a compensation claim, disciplinary procedure is fairly distinctive in terms of the specific procedure and decision-making bodies. Thus, for example, the first instance disciplinary proceedings for minor disciplinary offenses are conducted by the prison warden, who does not have to be a law graduate. Furthermore, the Rules on Disciplinary Procedure against Convicted Persons regulate the procedure itself, but the Criminal Procedure Code shall be applied accordingly for anything not prescribed by the Disciplinary Procedure Rules. Therefore, the decision on the compensation for damage is made by an underqualified person, who is not a lawyer (law graduate) and who is expected to interpret and apply the law.

Another situation exists when the convict has caused damage to the prison facility, but without committing a disciplinary offense. In such a case, the question arises whether the first instance body conducting the disciplinary proceedings shall decide on the compensation for damage. It seems that the response to this question can be affirmative, but it also raises a new question of whether it should be the warden or the disciplinary commission making a decision considering that they are the first-instance disciplinary authorities that conduct disciplinary proceedings depending on the gravity of the offense.

\section{WHO IS GUARDING PRISONS IN THE REPUBLIC OF SERBIA?}

It is quite logical that persons deprived of liberty cannot leave the penitentiary when they wish. They can do so only in cases which are explicitly prescribed in the regulations. However, convicts may attempt to unlawfully leave the penitentiary, resorting either to escape or unpermitted departure from the premises (Milić, 2017, pp. 813-823). Every person has a desire to get out of the penitentiary as soon as possible, to regain their freedom. However, this does not mean that every convicted person has the desire to escape from the penitentiary. As a rule, the persons sentenced to short-term imprisonment and those who have committed an act of negligence do not have this desire. Also, persons who have been punished for a misdemeanor or convicted of an economic offense have no desire to escape. There are certainly exceptions to these rules. In this regard, there are different prisons of different types in the Republic of Serbia, but,

\footnotetext{
${ }^{3}$ See Article 59 of the Rulebook on Disciplinary Procedure against Convicted Persons, "Official Gazette RS ", No. 79/2014.
} 
viewed from the security standpoint, it is common for them all that prison guards present an obstacle to their escape.

Thus, Article 14 of the Act on Execution of Criminal Sanctions (ECS Act) stipulates that, based on the degree of security, prisons may be open, semi-open, closed, and closed -special security prisons. There are no physical and technical barriers to escape in open-type prisons. In semi-open prisons, the elementary obstacle to escape is the security personnel. In addition to the security staff, there are other physical and technical barriers preventing escape in closed institutions, and there are further physical and technical barriers in closed special security institutions that ensure the highest level of security. Based on the above, we can conclude that the Security Service is an obstacle to escape prisons of all security levels.

The prisons in the Republic of Serbia are guarded by the Security Service. This service, as a unique formation of the Directorate for the Execution of Criminal Sanctions, takes care of the security of people and property in prisons, escorts convicted and detained persons, participates in the establishment and implementation of the convicted persons' treatment programs, and performs other tasks stipulated by the law. The security service shall be organized in such a way as to ensure the efficient performance of its tasks. Depending on the size and type of prison, the security service may comprise: a duty service, external security, internal security, an escort service, and a special unit. Security jobs are performed on a daily and continuous basis, in shifts.

The members of the security service have the status of authorized officers; they are authorized to carry weapons, inspect the prison premises, search and frisk persons, conduct body examination (except for body cavity searches, which are performed by a health care professional), apply measures for maintaining order and security in prison, and perform other tasks specified by the law.

\section{Types of Coercive Measures that can be Applied to Convicted Persons}

The types of coercive measures that can be applied to convicted persons vary depending on which law applies to sentenced persons. Considering the legal framework pertaining to these persons, we can distinguish "ordinary convicts" and "special convicts", depending on the law which applies to them during the execution of imprisonment (Grujić, Milić, 2015 , p. 819-830). While serving their sentence in a penal institution, convicted persons may be subject to the Act on Execution of Criminal Sanctions (hereinafter: ECS Act) or to the Act on Execution of Imprisonment for Organized Crime (hereinafter: EIOC Act). ${ }^{4}$ The EIOC Act is a lex

\footnotetext{
${ }^{4}$ Act on Execution of Imprisonment for Organized Crime Offenses, Official Gazette
} $R S$, No. 72/2009 and 101/2010. 
specialis in relation to the ECS Act, and it does not fully regulate the execution of the prison sentence, but instead applies the provisions of the ECS Act accordingly.

Both laws prescribe coercive measures that can be applied to convicted persons in almost identical ways. Coercion measures against sentenced persons can be applied by security officers. Certain coercive measures may be applied by members of the security service on their own initiative, of course, provided that the conditions are met. Certain coercive measures can only be used if ordered by the prison warden.

\section{Coercive Measures under the Law on Execution of Criminal Sanctions}

The Act on Execution of Criminal Sanctions (ECS Act) prescribes what measures of coercion can be applied to convicted persons. The legislature has chosen to explicitly address this issue. As prescribed, the convicted persons may be subjected to: 1) use of physical force; 2 ) restraining or tying at-risk prisoners; 3 ) solitary confinement, separation or isolation; 4) use of a rubber stick; 5) use of water jets; 6) use of chemical agents; and 7) use of firearms (Art. 143 of the ECS Act). Therefore, only these six measures can be applied against "ordinary convicts". Certainly, the strictest coercion measure is the use of firearms, which may be used by the security officer on his own initiative (assessment). The use of water jets and chemical agents can only be ordered by the warden (in extraordinary circumstances).

\section{Coercive Measures under the Law on Execution of Imprisonment for Organized Crime Offenses}

In recent years, Serbian criminal law and criminal procedure law have been going through a very dynamic development period. Drafts, proposals for amendments, or completely new legal texts are quite common, and it is hard to avoid the impression that they keep replacing one another at high speed (Ristivojević, 2015, p. 3). The reform did not spare criminal enforcement law either. The Act on Execution of Imprisonment for Organized Crime Offenses (EIOC Act), adopted in 2019, generally applies to the perpetrators of organized crime, but it may also apply to persons convicted of other crimes (Milić, 2017, pp. 468-469).

The EIOC Act also prescribes what coercive measures can be applied to those convicted persons to whom it applies. It prescribes the following coercive measures: 1) use of physical force; 2) binding; 3) separation; 4) use of a rubber stick; 5) use of sniffles with water; 6) use of chemical agents; 7) the use of electromagnetic (electronic) non-lethal means; 8) the use of acoustic-optical non-lethal means; 9) the use of kinetic non-lethal agents; 10) use of firearms (Article 46 of the EIOC Act). We see that this law prescribes three coercive measures more than the ECS Act. It is interesting to 
see what coercive measures are prescribed by the Police Act. ${ }^{5}$ Specifically, under this law, coercive measures are 1) physical strength; 2) irritant sprayer; 3) electromagnetic means; 4) baton; 5) binding; 6) special vehicles; 7) service dogs; 8) service horses; 9) means of prevention; 10) devices for ejecting water jets; 11) chemical agents; 12) special types of weapons; 13) firearms. (Article 222 of the Police Act). Although there are some overlaps in the types of coercion, this law prescribes a greater number of coercion types than the laws pertaining to the execution of criminal sanctions.

\section{When Coercive Measures can be Applied to Convicted Persons}

In order for the security officer to apply coercive measures, the conditions for their application must be fulfilled. Conditions for enforcement of coercive measures are prescribed by the ECS Act, the EIOC Act, and the Rulebook on the Measures for Maintenance of Order and Security in the institutions for the execution of criminal sanctions. ${ }^{6}$

\section{Conditions for Application of Coercive Measures Prescribed by the Law on Execution of Criminal Sanctions (ECS Act)}

Pursuant to the ECS Act, coercive measures against a convicted person can only be applied when it is necessary to prevent: 1) the escape of the convict; 2) physical assault on another person; 3) causing injury to another person; 4) self-harm; 5) causing considerable material damage; 6) active and passive resistance of the convicted person (Article 142, paragraph 1 ECS Act). This Act also regulates active and passive resistance.

Active resistance means any opposition of a convicted person to lawful official measures, actions and orders of an official or authorized person by hiding behind or holding onto a person or object, by abduction, by likelihood that some person will be attacked, or by a similar action. Passive resistance means any opposition of a convicted person to abide by lawful official measures, actions and orders of an official or authorized person by pretending not to hear an order, or taking a kneeling, sitting, lying or similar position (Art. 42 paragraphs 2 and 3 of the ECS. Act).

Conditions for Application of Coercive Measures Prescribed by the Law on Execution of Imprisonment for Organized Crime (EIOC Act)

Coercive measures against the convicted person can only be applied when it is necessary to prevent: 1) the escape of the convicted person; 2) physical assault, or causing injury to another person; 3) self-harm or

\footnotetext{
${ }^{5}$ The Police Act, Official Gazette of RS, no. 6/2016, 24/2018 and 87/2018.

${ }^{6}$ Rulebook on Measures for Maintaining Law and Order in the Institutions for Execution of Criminal Sanctions "Official Gazette RS ", no. 105/2014.
} 
suicide of the convicted person; 4) causing material damage; 5) active and passive resistance of the convicted person (Art. 142 paragraph 1 of the EIOC Act).

This law also prescribes what is considered to be active and passive resistance. Active resistance implies any opposition of a convicted person to lawful official measures, actions and orders of an official carried out by hiding behind or holding onto another person or object, by abducting, by the likelihood of attacking another person, or by taking similar actions. Passive resistance implies any opposition of a convicted person to lawful official measures, actions and orders of an official carried out by pretending not to hear an order, or by taking a kneeling, sitting, lying or similar position.

\section{SPECIAL MEASURES TO CONVICTED PERSONS}

Special measures can also be applied to convicted persons at these institutions (Milić, 2017, pp. 372-379). These are preventative measures that can be applied under certain conditions. These measures apply even though the convict has done nothing contrary to the prison rules. In order to implement specific measures, it is sufficient that there is a danger that the convicted person may "take certain actions". Specific measures are determined by the prison warden or by a person authorized by him. The previously mentioned laws also contain provisions regarding special measures.

\section{Special Measures under the Law on Execution of Criminal Sanctions}

According to the ECS Act, special measures are: 1) seizure and temporary holding of things whose keeping is otherwise permitted; 2) accommodation in a special secured room without dangerous things; 3) accommodation under enhanced supervision; 4) placing the convict in solitary confinement; 5) testing for infectious diseases or psychoactive substances.

The ECS Act also regulates in detail when each measure can be applied to convicted persons. It also prescribes how long certain measures can last and how they can be executed.

\section{Special Measures under the Law on Execution of Imprisonment for Organized Crime}

Under the EIOC Act, specific measures are: 1) seizure and temporary holding of things that are allowed to be kept in inmates' possession; 2) accommodation in a special secured room without dangerous things; 3) placing the convict in solitary confinement; 4) testing for infectious diseases or psychoactive agents. This Act has no further provisions in terms of special measures, which means that the ECS Act is applied according to all other issues. 


\section{When special measures can be applied to convicted persons}

In order to apply special measures to convicted persons, certain conditions have to be fulfilled. So, just like in the case of special measures, the ECS Act and the EIOC Act prescribe (in an almost identical way) the conditions under which the measures are applied. We believe that the EIOC Act does not need to transcribe provisions from the ECS Act that regulate legal issues in the same way, given that the ECS Act applies subsidiarily to all issues which are not regulated by the EIOC Act.

\section{Conditions for the Implementation of Special Measures Prescribed by the Law on Execution of Criminal Sanctions}

Under the ECS Act, special measures may be exceptionally ordered against a convicted person when there is a danger of escape, violent conduct, self-harm or endangering order and security of some other kind, which cannot otherwise be eliminated. A special measure will be determined depending on the type of existing danger.

\section{Conditions for the Implementation of Special Measures Prescribed by the Law on Execution of Imprisonment for Organized Crime}

The EIOC Act only transcribes the provisions prescribed by the ECS Act. These special measures may be exceptionally ordered against a convicted person when there is a danger of escape, violent conduct, selfharm or endangering order and security of some other kind, which cannot otherwise be eliminated.

\section{CONCLUSION}

The existence of two legislative acts, Act on Execution of Criminal Sanctions and the Act on Execution of Imprisonment for Organized Crime, regulating the execution of imprisonment in penal institutions, clearly indicates that there are two groups of convicts in the Republic of Serbia. Considering the two laws (the ECS Act and the EIOC Act), it is clear that the EIOC Act is a lex specialis, which explicitly stipulates that the ECS Act will be applied accordingly to any issues that it does not regulate. In this regard, it is unnecessary for the EIOC Act to contain identical provisions, which are prescribed by the ECS Act. Therefore, some of the provisions of the ECS Act are merely transcribed into the EIOC Act, which is unnecessary. Such a decision by the legislature, at the very least, only burdens the text of the law itself. It is clear that the legislator has made every effort to address the issue of liability of convicted persons for offences committed in the course of serving their prison sentences. Different types of liability (criminal, disciplinary, material) are assessed in the same manner with different categories of convicted persons. Such a 
conclusion is based on the fact that the EIOC Act does not prescribe specific provisions on the liability of convicted offenders. There are some differences with respect to law enforcement measures regarding the law applicable to convicted persons.

The prison sentence of the convicted person is individualized until they serve the determined sentence. At the same time, convicts are constantly monitored by prison authorities and any disorderly conduct is recorded in the penal institution records. Such records may also affect the convict's treatment and individualization of the awarded sentence during the execution of punishment; as a result of misconduct, the convicted person may be denied some rights, benefits or privileges. As a result of this setback, the convicted person may be placed into a more rigorous ward or group, where the scope of his individual rights and benefits would be significantly restricted.

\section{REFERENCES}

Clear, T., Cole, G., Reisig, M. (2009), American Corrections, Thomson Higher Education, USA, 278

Dimovski, D., Kostić M., (2018), Karakteristike osuđeničih bandi u Republici Srbiji [Characteristics of convicted gangs in the Republic of Serbia], Teme, Univerzitet $u$ Nišu, br. 3, 1043-1060.

Drakić, D., Milić, I., (2016). Utvrđivanje istine u disciplinskom postupku koji se vodi protiv osuđenog za vreme izdržavanja kazne zatvora, [Determining the truth in disciplinary proceedings against a convict while serving a prison sentence] Zbornik radova Pravnog fakulteta u Novom Sadu, br. 2., 475-491.

Grujić Z., Milić, I., (2015). Prava lica osuđenih na kaznu zatvora u krivičnom izvršnom zakonodavstvu Republike Srbije [Rights of persons sentenced to imprisonment in the criminal executive legislation of the Republic of Serbia], Naučni skup „Dvadeset godina Dejtonskog mirovnog sporazuma”, Pale, 819-830.

Krivični zakonik, Službeni glasnik RS, broj 85/2005, 88/2005, 107/2005, 72/2009, 111/2009, 121/2012, 104/2013, 108/2014, 94/2016 i 35/2019;

Milić, I., (2017). Bekstvo iz zatvora - krivično delo ili disciplinski prestup? [Prison break criminal or disciplinary offense?], Zbornik radova Pravnog fakulteta u Novom Sadu, broj 3, 813-823.

Milić, I., (2017). Individualizacija kazne zatvora - kriminološki, krivičnopravni i penološki aspekt - doktorska disertacija, [Individualization of imprisonment - criminological, criminal law and penological aspect - doctoral disertation], Novi Sad, 468-469.

Milić, I., (2017). Posebne mere prema osuđenim licima [Special measures against convicted persons] Zbornik radova „Anomija društva i posledice”, Banja Luka, 372-379.

Milić, I., Dimovski, D., (2016). Kažnjavanje osuđenih lica - disciplinske mere [Punishment of convicted persons - disciplinary measures], Zbornik radova Pravnog fakulteta u Novom Sadu, br. 1, 219-231.

Pravilnik o disciplinskom postupku prema osuđenim licima, Službeni glasnik RS, broj $79 / 2014$.

Pravilnik o merama za održavanje reda i bezbednosti u zavodima za izvršenje krivičnih sankcija, Službeni glasnik RS, br. 105/2014.

Ristivojević, B., (2015). Istina kao glavna žrtva angloamerikanizacije domaćeg krivičnog prava: Darvinov rasad u srpskoj šumi, [Truth as a major victim of Anglo- 
Americanization of domestic criminal law: Darwin's seedlings in the Serbian forest] LV Savetovanje Srpskog udruženja za krivičnopravnu teoriju i praksu, Zlatibor, 3.

Zakon o izvršenju krivičnih sankcija, Službeni glasnik RS, br. 55/2014, 35/2019.

Zakon o izvršenju kazne zatvora za krivična dela organizovanog kriminala, Sl. glasnik RS, br. $72 / 2009$. i 101/2010.

Zakon o policiji, Sl. glasnik RS, br. 6/2016, 24/2018. i 87/2018.

\title{
ОДГОВОРНОСТ ОСУЂЕНИКА И ОДРЖАВАЫЕ РЕДА И БЕЗБЕДНОСТИ У КАЗНЕНИМ ЗАВОДИМА
}

\author{
Дарко Димовски ${ }^{1}$, Иван Милић ${ }^{2}$ \\ ${ }^{1}$ Универзитет у Нишу, Правни факултет, Ниш, Србија \\ ${ }^{2}$ Универзитет у Новом Саду, Правни факултет, Нови Сад, Србија
}

\begin{abstract}
Резиме
У пенитенцијарном систему Републике Србије, поред лица осуђених услед извршења кривичних дела, на издржавању казне затвора су и друга лица која су, на основу закона, лишена слободе. Другим речима, у казненим заводима налазе се и лица која су прекршајно кажњена затворском казном. Уједно, на издржавању казне затвора су и лица којима је у кривичном или прекршајном поступку изречена новчана казна или казна рада у јавном интересу, а која им је услед неплаћања, односне услед необављања рада у јавном интересу, замењена за казну затвора. Уколико одговорно лице, које је осуђено због учињеног привредног преступа, не плати новчану казну, она се замењује у казну затвора, те се шаље у казнени завод на њено издржавање. Осуђена лица у казненом заводу могу да учине неку радњу која је забрањена. Та забрањена радња може бити прописана као кривично дело или дисциплински преступ. С тим у вези, аутори су у раду објаснили кривичне и дисциплинске одговорности осуђеног лица у случају недозвољеног понашања. Иако у случају извршења кривичног дела од стране осуђеног лица не постоје никакве специфичности у односу на кривично дело почињено од стране лица на слободи, ипак постоји изузетак који прописује Кривични законик. Наиме, ако осуђени, који за време издржавања казне затвора или малолетничког затвора, учини кривично дело, за које закон прописује новчану казну или казну затвора до једне године, казниће се дисциплински. Уколико осуђена лица прекрше правила понашања у пенитенцијарним установама, чине дисциплински преступ. Дисциплинске преступе прописује ЗИКС и дели их на теже и лакше. Поред тога што осуђено лице може да учини кривично дело или дисциплински преступ, оно за време издржавања казне може да проузрокује штету заводу. У том случају, осуђени је под одређеним условима дужан да надокнади штету заводу. У другом делу рада аутори се баве службом за обезбеђење, те њиховим обавезама. Наиме, ова служба стара се о безбедности људи и имовине у заводу, спроводи осуђена и притворена лица, учествује у утврђивању и спровођењу програма поступања према осуђеном и обавља друге послове одређене законом. У наставку рада аутори се баве питањем могућности примене различитих врста принуде од стране припадника Службе за обезбеђење. Последњи део рада посвећен је посебним мерама. Реч је о превентивним мерама које могу да се примене под одређеним условима. То су мере које се примењују иако осуђени није учинио ништа што је противно затворским прописима. Услов за примену посебних мера је постојање опасности да осуђени може „предузети одређене радње”.
\end{abstract}

